\title{
DEVELOPING A LOGGING UNIT FOR MEASURING AND RECORDING POWER DATA USING ARDUINO BOARD
}

\author{
Samy G. Hemeda ${ }^{1}$, Abdulwahed M. Aboukarima ${ }^{2}$ and \\ Mamdouh Minyawi ${ }^{1}$
}

\begin{abstract}
A logging unit for measuring and recording power data for tillage implements was investigated. The system of sensor for a continuous and real time measurement of draft data is a set of electronic circuit made around the Arduino UNO board. It consisted of a conditioning circuit for strain gauges pull meter. The developed system was an alternative of the commercial data logger namely Daytronic system $10 K 4$ in draft measurement system (Khadr, 2008). As with the hardware, the Arduino integrated development environment is open source and can be down-loaded freely from the project's internet website for programming, serves for compiling and up-loading programs to the microcontroller. Laboratory evaluation demonstrated that the developed system has been successfully gathered data from strain gauge pull meter. The entire system was fixed on a tractor and a field experiment with chisel plow was conducted to evaluate the performance of the developed instrumentation system by determining the required chisel plow draft. The plowing speed measurement was done manually. The drawbar pull was measured at three tractor plowing speeds. The draft results were compared with those obtained through $\boldsymbol{A S A E}$ (2000) equation for chisel plow and the relative error was about 27\%. The very limited cost of the system presented in this paper could represent a step towards a more widespread application of accurate monitoring of tillage and tractor performance data potential, leading to an improvement of farm machinery management.
\end{abstract}

Key Words: Draft, tillage, Arduino, chisel plow.

\footnotetext{
${ }^{1}$ Researcher, Agric. Eng. Res. Inst., Agric. Res. Centre, Egypt.

${ }^{2}$ Senior Res., Agric. Eng. Res. Inst., Agric. Res. Centre, Egypt.
} 


\section{INTRODUCTION}

7 illage is a process of creating soil condition for seed germination and growth of crop (Al-Suhaibani and Ghaly, 2010). It is

1 considered one of the biggest farm operations as tillage operation requires the most energy on the farm (Jithender et al., 2017). The tillage can be performed by the primary tillage implements like moldboard plow, disk plow, chisel plow and rotary plow. These implements are attached to a tractor, which is a self-propelled power unit having wheels or tracks for operating agricultural implements. For a tractor-implement system, it is necessary to know the implement draft requirement. Draft is defined as the force required for pulling an implement in the horizontal direction of travel (Al-Hamed and Al-Janobi, 2001). It is usually measured using particular instrumentation systems (Elashry et al., 1994; Al-Janobi, 2000; Younis et al., 2010; Singh and Singh, 2011; Rasool et al., 2017). Such system can be consisted of a strain gauge pull meter and data logger (Daytronic data PAC model 10k4) as reported by Khadr (2008) as shown in Figure (1).

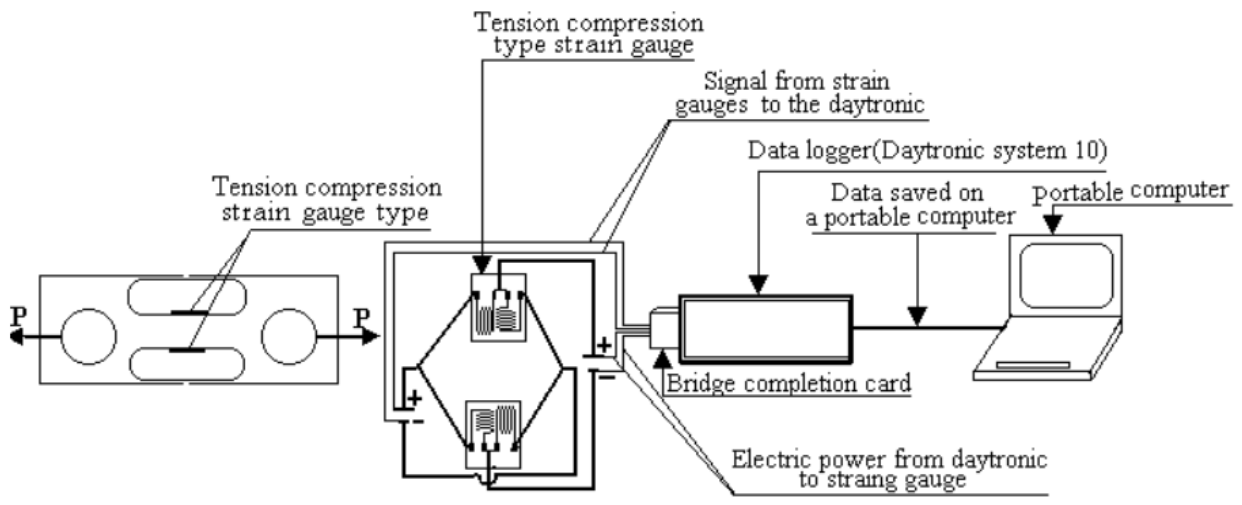

A) Strain gauge dynamometer.

B) Strain gauge wiring and connecting with data logger(daytronic system 10) and a portable computer.

Figure (1). Sketch drawing for the strain gauge pull meter with its wiring and connections with data logger (Daytronic 10k4) and a portable computer (Khadr, 2008).

The major item in the system (Figure 1) is the commercial data logger (Daytronic 10k4) as it is expensive. Therefore, the availability of simple yet accurate tools for monitoring draft of tillage implements will become 
a key factor for proper farm machinery management. This topic has been the subject of intensive research, and a wide range of methods for monitoring the draft requirements of tillage implements has been proposed (Al-Suhaibani et al., 2006; Younis et al., 2010). These include techniques to measure draft (Al-Janobi, 2000) and other performance parameters like fuel consumption (Nada, 2003) or PTO torque (ElGwadi, 2005).

Load measuring systems usually consist of a measuring chain which comprises transducers, instrumentation and an indicator as depicted in Figure (2) as reported by Hoffmann (2001). The transducer converts the physical input signal of the measuring system into a measurable output signal which can be a voltage, current or charge. In some cases, there might be a chain of transducers transforming the input signal in several steps (Bolton, 1994). For instance, a strain gauge load cell consists of an elastic element which transforms the applied force into strain. The strain is converted to a change in resistance by a strain gauge resistor. The output of the transducer is transferred to the instrumentation, which comprises signal conditioners, a microcontroller and memory. Signal conditioners process the output signal of the transducers in order to enable processing of the signal with a micro controller, which records it in the memory. Data acquisition is especially needed in case of rapidly changing forces. Besides signal conditioning and data acquisition the instrumentation is needed to power the transducers in case of passive sensing elements (Mayer, 2016).

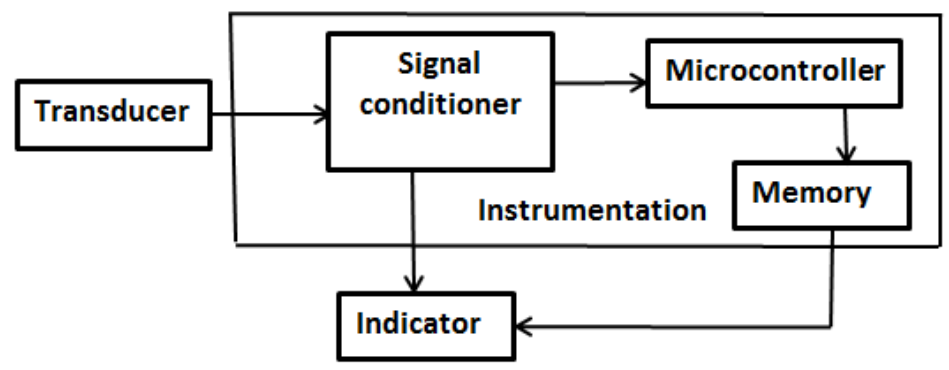

Figure (2). Common measuring chain Hoffmann (2001).

Strain gauge pull meter for monitoring draft requirements of tillage implements are, therefore, an excellent tool for collecting continues draft 
data. Electronic devices have made it possible to implement systems of automatic data acquisition. Commercially available systems are, however, often expensive and sometimes complicated to operate (Teli and Mani, 2015). Recent advances in electronics have led to the development of inexpensive components which can be assembled into fully operational sensing and monitoring systems (Dedrick et al., 2000; Fisher and Gould, 2012; Fisher and Kebede, 2010; Thalheimer, 2013; Tatović et al., 2016). Arduino could be providing inexpensive open-source electronics prototyping platform based on flexible, easy-touse hardware and software (David et al., 2007). The Arduino Uno (Figure 3) is a single-board microcontroller, intended to make the application of interactive objects or environments more accessible. It has 14 digital I/O pins which can be used to interact with various peripherals.

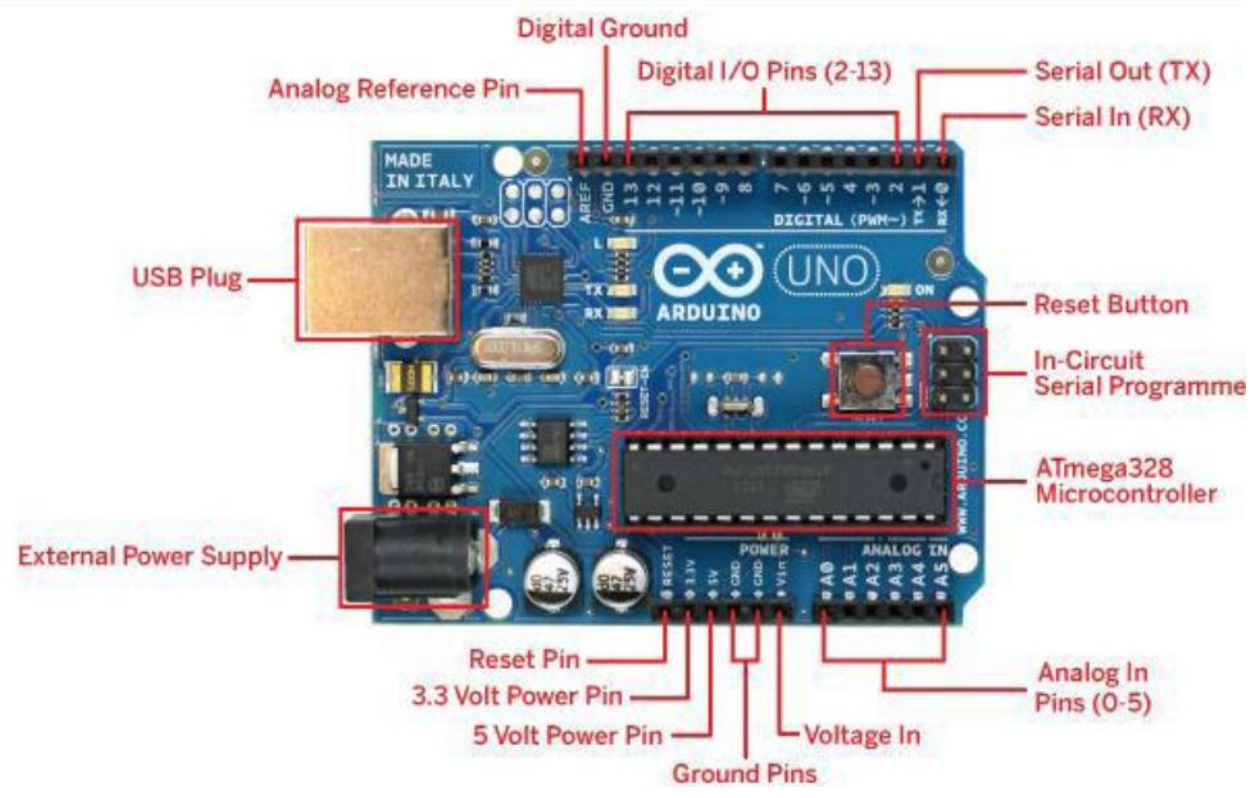

Figure (3).Typical Arduino Uno commercial microcontroller components (Kashyap, 2015).

The Arduino also has six analog pins which are internally connected to an analog to digital convertor (ADC) to measure a range of analog voltages (Kadimi and Dheeraj, 2014). It can be powered by a laptop with a USB cable or by an AC-to DC adapter or 6-20 V battery. Arduino-compatible custom sensor expansion boards, known as shields, 
can be developed to directly plug into the standardized pin-headers of the Arduino board. They enable Arduino to connect to several sensors (Ferdoush and Li, 2014; Hut, 2013).

Arduino plays a vital role in helping agricultural researches by utilizing it in different applications. Kadimi and Dheeraj (2014) built a costeffective device to calculate the area being plowed by a farm tractor as it moves ahead. It consisted of an ATMEGA328 Microcontroller (Arduino) which was interfaced with a Hall sensor and the digital compass. Almaliki et al. (2016) developed an instrumentation package for measuring the tractor performance. The package included the data logging system and the transducers for measuring fuel consumption, actual velocity, theoretical velocity, drawbar pull and plow depth. The data logging system consisted of an Arduino board and portable computer (laptop) linked via a USB port.

The objective of this paper is to propose an easily, low cost draft measuring system that requires minimal soldering of electronic components to be an alternative commercial data logger such as Daytronic 10k4 in Khadr (2008) for draft measuring system. The presented system was based on the open-source microcontroller platform, Arduino, and a few additional components, and it is designed to accomplish accurate measurements of draft force of tillage implements along the field and to store the data in memory for later retrieval. A suitable software code for the microcontroller is freely available. The system has been tested for measuring the draft for a chisel plow.

\section{MATERIALS AND METHODS}

The core of the data acquisition and logging system presented here consisted of a microcontroller board (Figure 4), HX711 (an amplifier for strain gauge) as shown in Figure (5) and a strain gauge pull meter (Figure 6). Power is provided by an electronic circuit to provide $5 \mathrm{~V}$ from tractor's battery. Laboratory primary testes on the amplifier for strain gauge were conducted as shown in Figure (7). The schematic diagram of the circuit is presented in Figure (8). 


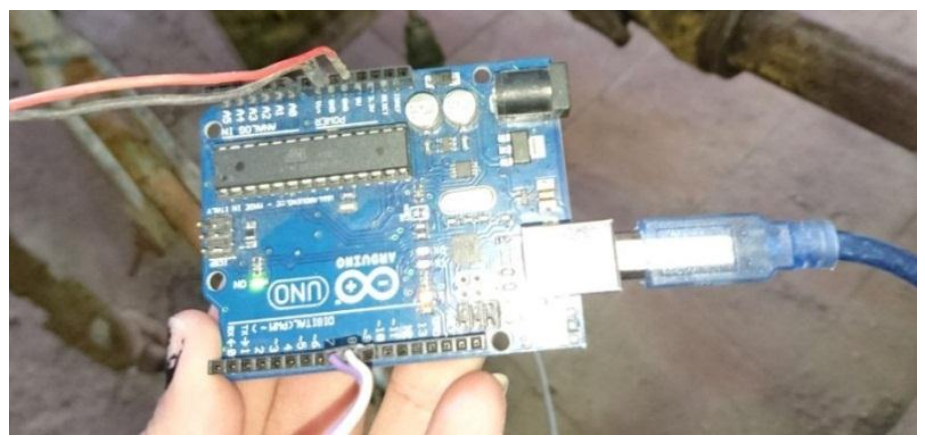

Figure (4). Arduino (a microcontroller board).

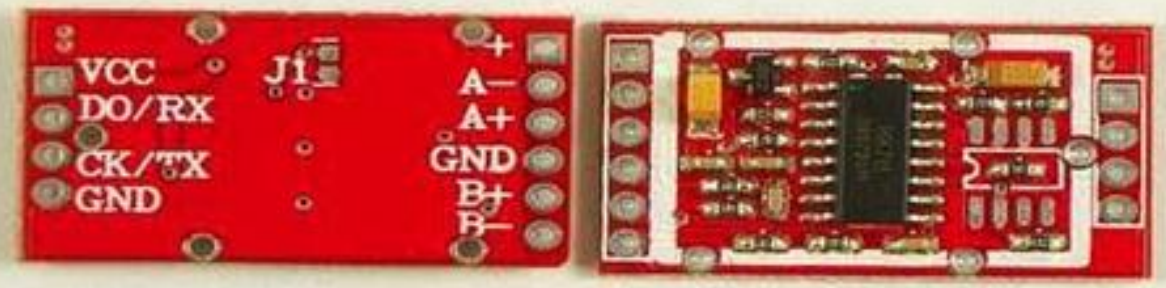

Figure (5). HX711 (an amplifier for strain gauge).

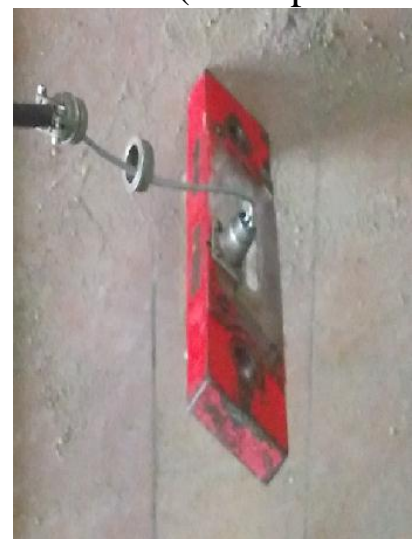

Figure (6). The strain gauge pull meter.

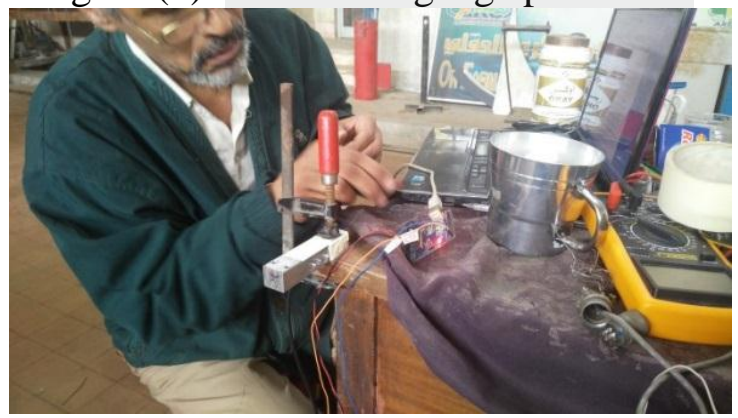

Figure (7). Primary testes on the amplifier for strain gauge. 


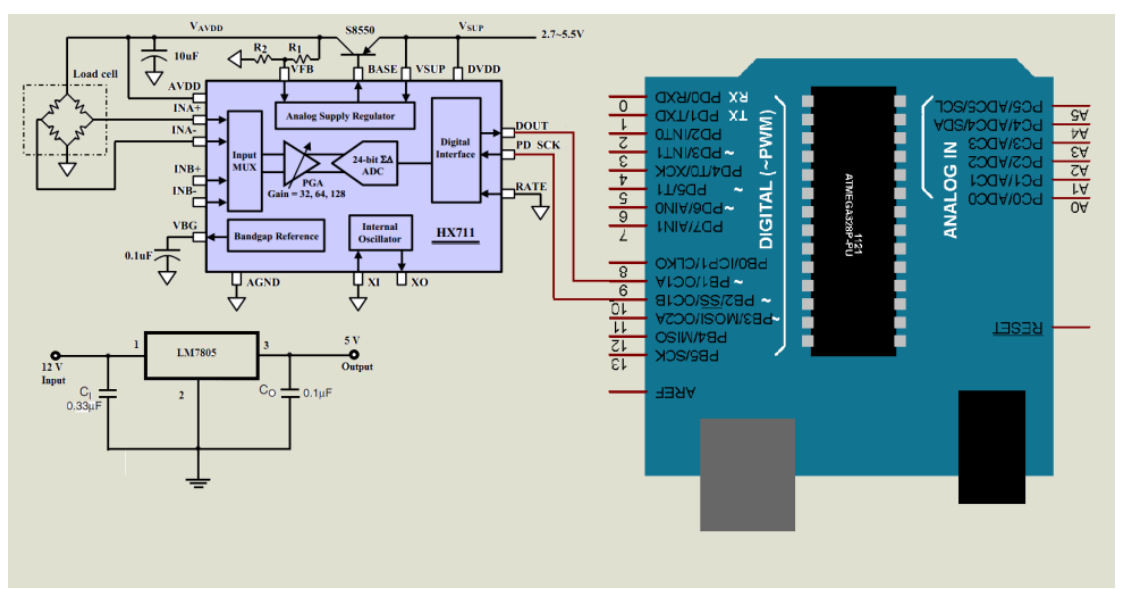

Figure (8).The schematic diagram of the circuit.

\subsection{Microcontroller board}

There is a wide choice of commercially available microcontrollers. Most of them require additional external components and/or specific programming interfaces to become fully operational units, and therefore demand a substantial degree of technical expertise both for assembly and programming. In recent years, an open source project has been launched, designed to make the use of microcontrollers in multidisciplinary projects more easily accessible. The Arduino system consists of boards equipped with Atmel AVR microcontrollers and complementary components needed for regulated power supply, serial communication and interfacing with external hardware. The microcontroller is equipped with a boot loader, which enables programming via open-source PC software without additional specific hardware (Thalheimer, 2013).

The mainboard is the Arduino UNO (Figure 4). This board has digital I/O pins (2-13), analog in pins (0-5) and a USB connection. It contains everything needed to support the microcontroller. The Arduino UNO can be powered either via the USB connection or using an external supply of 7 to 12 volts. It can provide a $3.3 \mathrm{~V}$ output voltage. The Arduino UNO has Flash memory to store the program. The board contains firmware that manages the various modules of measurement.

As with the hardware, the Arduino integrated development environment is open source and can be down-loaded freely from the project's internet website (http://www.arduino.cc). This application is written in Java and, 
besides providing the environment for programming, serves for compiling and up-loading programs to the microcontroller. Programmes are written in a language similar to $\mathrm{C} / \mathrm{C}++$, with some simplifications and modifications. Detailed reference about boards and the programming language, including explanatory examples, can be found on the Arduino website (http://www.arduino.cc).

\subsection{Strain gauge pull meter}

Strain gauge load cells are the most commonly used sensors to measure loads and therefore easily available (Ştefănescu, 2011). The load cells consist of an elastic element and several strain gauges placed on the element. The strain gauges detect the elongation of the elastic element. If there are local strains, the resistance of the strain gauges changes. Strain gauges basically consist of a length of conducting material, which might be considered as a wire. In case the wire is stretched the diameter decreases and the electrical resistance increases. The force acting on the elastic element can be determined with the help of the measured strain, the material properties and the geometry of the elastic element. In order to detect the force accurately a linear stress-strain relationship of the elastic element is needed. Foil strain gauges, semiconductor strain gauges, thin-film strain gauges and wire strain gauges are available (Mayer, 2016). Foil strain gauges; illustrated in Figure (9) are the most commonly used. They consist of a measuring pattern made of metal foil placed on backing material made of polyamide or epoxy.

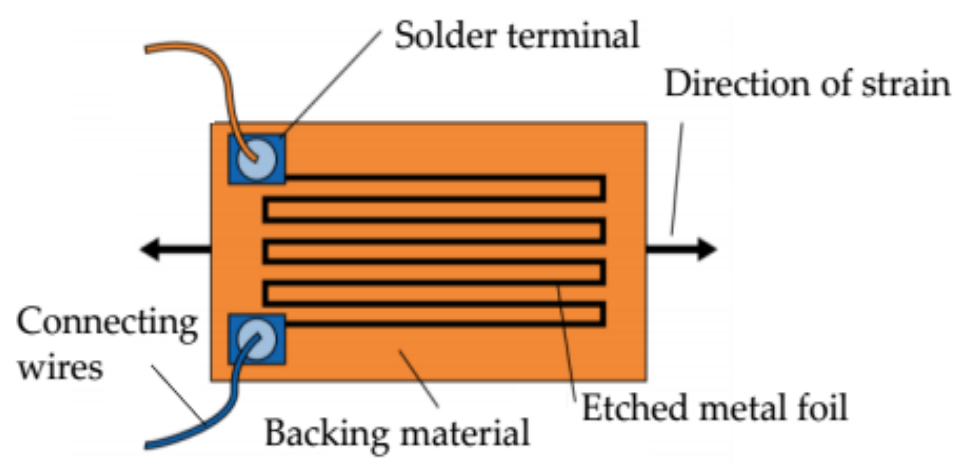

Figure (9). Strain gauge with connecting wires (Mayer, 2016). 
Available calibrated strain gauge drawbar pull meter was utilized in this study to measure draft force of a tillage implement (Elashry et al., 1994; Younis et al., 2010). The capacity of the pull meter was $10000 \mathrm{~kg}$ (Figure 6). Two sets of CEA-06-187UV-350, $180^{\circ}$ rosette, $350 \mathrm{ohm}, 2.1$ gauge factor strain gauges are bonded at $45^{\circ}$ shear planes at two opposing positions on the outer surface of the iron section (Figure 10). The bonded strain gauges are connected in full bridge configuration. The excitation source for the strain gauge was supplied from the Arduino board through special connectors.

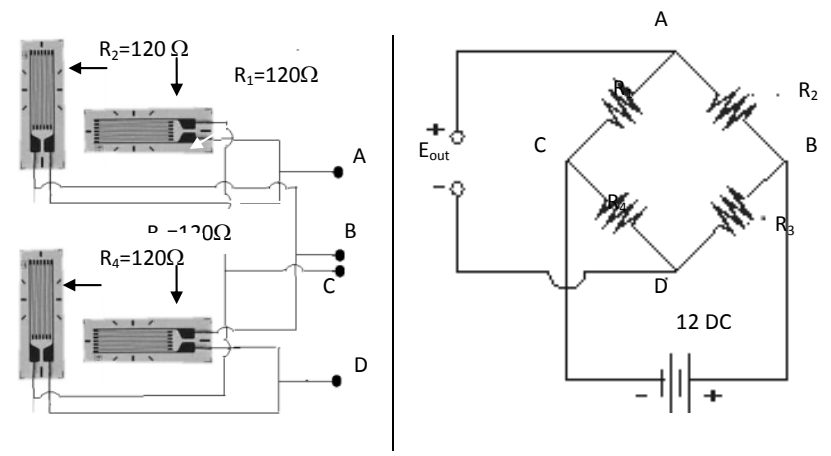

Figure (10). Wiring diagram of the Wheatstone strain gauge bridge.

\subsection{Data storage and transfer}

The Arduino board is already equipped with the required electronic interface with computer. On the PC, a suitable terminal programme makes it possible to retrieve and save the data transferred from the microcontroller's memory. Data can be downloaded from the microcontroller board to the PC via a serial connection.

\subsection{Power calculation}

Drawbar power $(\mathrm{DB}, \mathrm{kW})$ is calculated as follows:

$D B=V \times F$

Where $\mathrm{F}$ is measured draft $(\mathrm{kN})$ and $\mathrm{V}$ is plowing speed $(\mathrm{m} / \mathrm{s})$.

\subsection{Laboratory evaluation}

With the laboratory power supply unit, the signal conditioning unit which is needed in order to transfer the changing resistance of the strain gauges to a voltage signal, which the Arduino UNO board can digitalize, was tested. The forces acting on the pull meter cause strains which induces a 
change of resistance at the strain gauges. With the use of the Wheatstone bridges, this change of resistance can be translated to voltage which is amplified by the instrumentation amplifiers. The amplified voltage is sensed by the A/D-converter and transformed to voltage increments of the measuring range. The Accuracy of the signal conditioning unit was tested by recording data when there was no load on the pull meter. The arrangement for pull meter calibration is shown in Elashry et al. (1994) to generate the calibration function and after that the Arduino sketch was saved and uploaded to the Arduino. Once the pull meter is calibrated it can be used to measure the draft of a tillage implement. Daytronic 10k4 was utilized to compare laboratory calibration (Figure 11). In the field, due to previous calibration, the according draft force value for a certain resistance change is known.

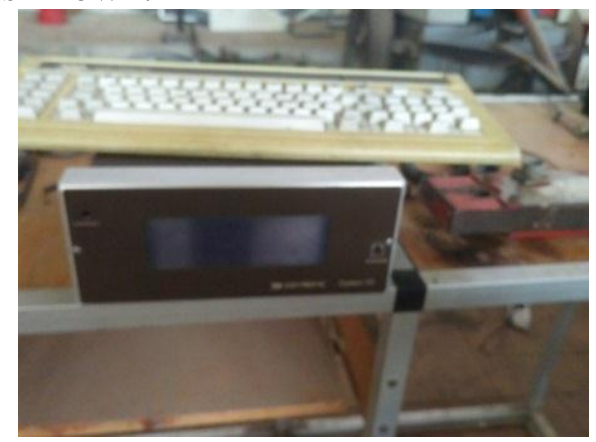

Figure (11). Daytronic 10k4 was utilized to compare laboratory calibration.

\subsection{Field experiments}

To validate the developed data logger system, filed experiments were undertaken with chisel plow. The strain gauge pull meter, 10 ton, Figure (6) was attached with a horizontal chain between two tractors to measure the draft of the chisel plow. A Kubota M1- tractor of $93 \mathrm{hp}$ was used to attached the chisel plow; whereas the front tractor Belarus, $90 \mathrm{hp}$ was used to pull the Kubota tractor with the attached chisel plow through the strain gauge pull meter. The Kubota tractor was working on the neutral gear but the chisel plow in the operating position; the draft force was recorded and saved on the Arduino board which was on the tractor. On the same field the implement was lifted from the soil and the rear tractor was pulled to record and save the idle draft. The difference gave the draft 
requirement of the chisel plow, average draft for each plowing speed was computed from draft observations through the experiment, Khadr (2004 and 2008) used the same strain gauge pull meter and the same draft measurement procedures but the data logger was Daytronic 10k4. The simple method for draft force measurement of the implement during tillage operations officially proposed by Regional Network for Agricultural Machinery (RNAM) (RNAM, 1995) was generally considered in the study. The plowing speed was calculated from the time required by the tractor and the chisel plow to cover the distance of five revolutions for the tractor rear wheel through tillage operation, at which the tractor and the chisel plow usually state speed. The used chisel plow was seven tools with total width of $175 \mathrm{~cm}$. The experiments were conducted in a sandy clay loam soil having a soil bulk density of 1.38 $\mathrm{g} / \mathrm{cm}^{3}$, soil moisture content of $11.24 \% \mathrm{db}$ and clay, sand, and silt percentages of $30 \%, 52 \%$ and $18 \%$, respectively. The draft of three plowing speeds was measured where the chisel plow was operated at plowing depth of $14 \mathrm{~cm}$.

\subsection{Draft estimation by ASAE (2000)}

Harrigan and Rotz (1994) proposed a simple function for a range of soil conditions and machine specific parameters to predict the draft of farm implements under general conditions, where draft is a function of soil type and the speed at which the implement is pulled. They presented reference tables for soil and machine specific parameters. These tables and mathematical expressions were adopted by the American Society of Agricultural Engineers to revise the ASAE Standards for Agricultural Machinery Management Data as part of ASAE D497.4 to predict draft requirements for tillage implements in several soil types (ASAE, 2000). This standard uses a simplified draft prediction equation proposed by as follows:

$\mathrm{D}=\mathrm{Fi}[\mathrm{A}+\mathrm{B} \times \mathrm{S}+\mathrm{C} \times \mathrm{S}] \times \mathrm{W} \times \mathrm{T}$

Where $\mathrm{D}$ is the implement draft force $(\mathrm{N})$; $\mathrm{F}$ is a dimensionless soil texture adjustment parameter, $i$ is soil factor and it is $=1$ for fine, 2 for medium and 3 for coarse texture soils. ASAE (2000) reported finetextured soil is described as high in clay content, medium textured is 
loamy soils, and coarse textured is sandy soils. A, B and C are machinespecific parameters; $S$ is plowing speed $(\mathrm{km} / \mathrm{h}) ; \mathrm{W}$ is implement width (m); and T is tillage depth (cm). The objective of the Eq. (2) is to provide a draft prediction equation that is applicable to a wide range of soil conditions. The Eq. (2) provides a good estimate of tillage implement draft but indicates that a range in draft of up to $\pm 50 \%$ can be expected within the same broad textural soil class. In this study, soil type was classified to be medium texture, thus, based on ASAE (2000), F2 was selected to be 0.85 and for chisel plow A is 390 and B is 19 and C is zero, $\mathrm{W}$ is $1.75 \mathrm{~m}$ and $\mathrm{T}$ is $14 \mathrm{~cm}$. Different research papers were considered Eq. (2) to compare draft data or to determine the draft requirements of a tillage implements (Al-Hamed and Al-Janobi, 2001; Zadeh and Kushwaha, 2006; Askari and Khalifahamzehghasem, 2013; Iman, 2017; Ranjbarian et al., 2017).

\section{RESULTS AND DISCUSSION}

The developed draft measuring system of the described design on the basis of an Arduino Uno board was utilized to measure chisel plow draft requirements under filed conditions. Three plowing speeds were selected by changing tractor gears. The Arduino board was fixed on the tractor and powered from tractor battery with volt regulator circuit. Data were sampled at $50 \mathrm{~ms}$ intervals. The stored data in the memory card of the data logger from the field trials was able to be down loaded into the hard disk of a computer at the laboratory for post processing. The purposes of the field tests were to validate the accuracy of the developed system. The obtained draft data were compared to draft data obtained by Eq. (2) (ASAE, 2000). The Arduino UNO was chosen due to its extremely low cost (its price was about 400 Egyptian pounds), ease of use, and ability to accurately acquire data. The Arduino served two main functions. The first of which was to power the strain gauge circuit and the second function was to acquire data from the pull meter. The code used in the Arduino was quite simple and available from Arduino web site. Figure (12) shows variations of the draft force with time for the selected plowing speeds which were $2.54,3.83$ and $4.75 \mathrm{~km} / \mathrm{h}$. The graph reveals the general pattern of draft according to plow position in the field over 
time. The graph also indicates a marked pattern of draft fluctuations of pull meter readings, which result from the variation in the soil properties.

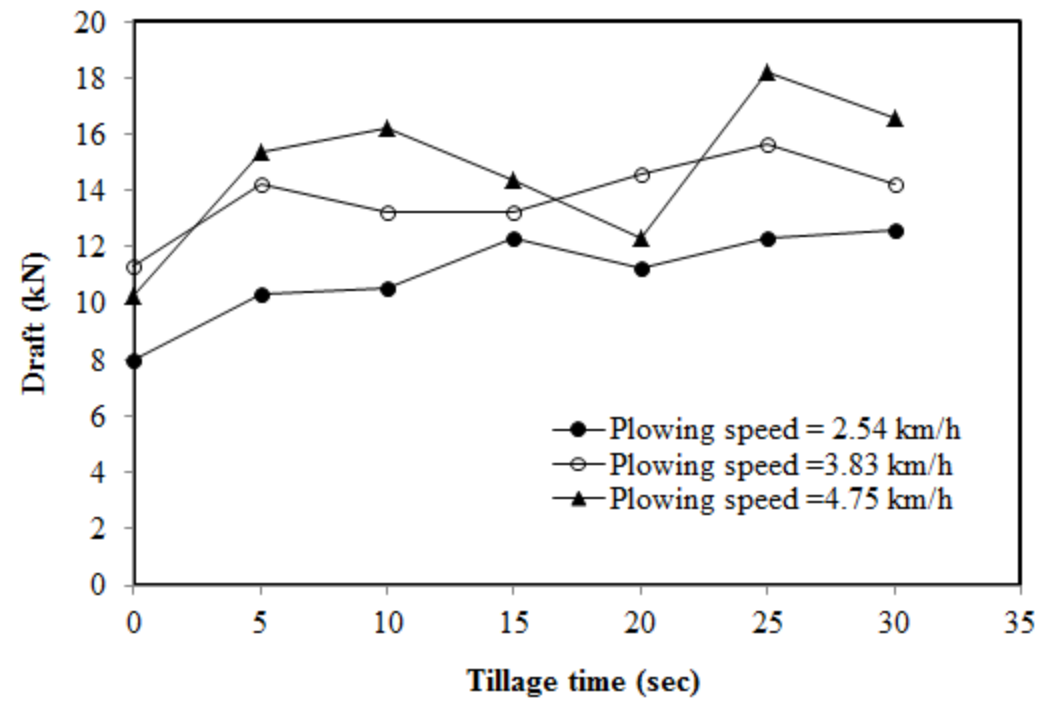

Figure (12). Variations of the draft force with time for the selected plowing speeds.

Average value was compared to data obtained from Eq. (2) and the results are shown in Figure (13). It is clear that increasing plowing speed results increase in draft. The effect of the plowing speed on the draft has been investigated by various researchers (Sahu and Raheman, 2006; Aboukarima, 2007; Khadr, 2008; Ghaly and Al-Suhaibani, 2010; Ndisya et al., 2016). The general observation has been that increasing the plowing speed results to an increase in the draft. For every plowing speed, relative error (Relative error $=$ (measuredpredicted)/measured*100) was determined and the average value was 27 $\%$, however, Askari and Khalifahamzehghasem (2013) reported relative error of $11 \%$ for comparing of chisel plow draft data with those from Eq. (2). The field trials demonstrated that the data logger and associated strain gauge pull meter were able to function successfully without giving problems under the harsh field environments. The drawbar power for the chisel plow was shown in Table (1) and it is clear that increasing plowing speed led to increase drawbar power. However, Nassir et al. (2017) showed that the increase in plowing speed from 1.48 
to $4.68 \mathrm{~km} / \mathrm{h}$ led to a significant increase in drawbar power of a chisel plow operating in a silty clay soil; however, for plowing speed of 4.68 $\mathrm{km} / \mathrm{h}$ and at plowing depth of $15 \mathrm{~cm}$, the drawbar power was about 18.16 $\mathrm{kW}$.

Table (1). The required power for the chisel plow.

\begin{tabular}{|c|c|}
\hline Plowing speed $(\mathrm{km} / \mathrm{h})$ & Power $(\mathrm{kW})$ \\
\hline 2.54 & 7.79 \\
\hline 3.83 & 14.67 \\
\hline 4.75 & 19.48 \\
\hline
\end{tabular}

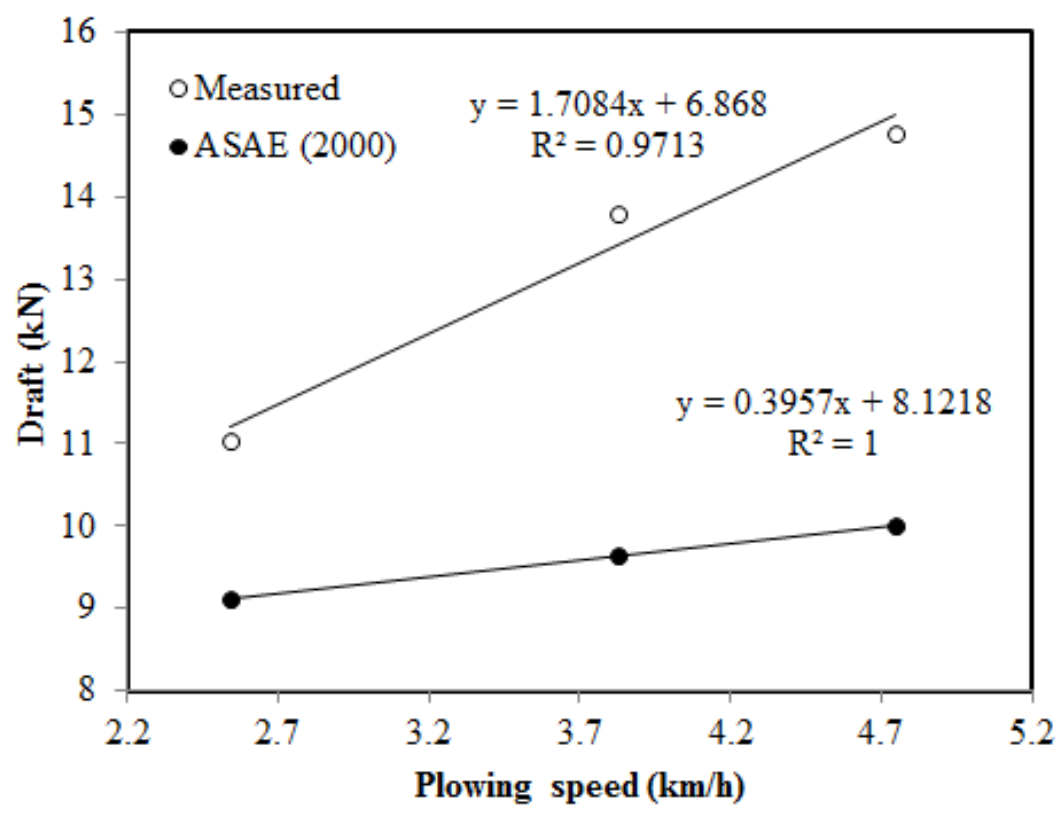

Figure (13). Effect of plowing speed on draft data.

\section{CONCLUSION}

The proposed electronic data acquisition system for draft data collection for a chisel plow based on the open source Arduino system, strain gauge pull meter, constitutes a very cost effective alternative to commercial data acquisition system. From a technical point of view, the system has proved to be accurate and reliable to collect draft data of a chisel plow operated in a sandy clay loam soil without any malfunction. The 
assembly of the system requires only minimal soldering and can, therefore, be easily set up also by users with only basic technical skills. The simplicity of construction, combined with its modest cost, could make this system a useful tool for gathering draft data of tillage implements for farm machinery management in particular.

\section{REFRENCES}

Aboukarima, A. M. (2007). Draft models of chisel plow based on simulation using artificial neural networks. Misr J. Agric. Eng., 24:42-61.

Al-Hamed, S.A. and A.A. Al-Janobi (2001). An Object-oriented program to predict tractor and machine system performance. Res. Bult., No. (106), Res. Cent. Coll. of Agri., King Saud Univ., pp. (524).

Al-Janobi, A. (2000). A data-acquisition system to monitor performance of fully mounted implements. Journal of Agricultural Engineering Research, 75(2): 167-175.

Almaliki, S., R. Alimardani and M. Omid (2016). Fuel consumption models of MF285 tractor under various field conditions. CIGR Journal,18(3):147-158.

Al-Suhaibani, S. A. and A. E. Ghaly, 2010. Performance evaluation of a heavy duty chisel plow at various tillage depth and forward speeds. American J. of Engineering and Applied Sciences, 3 (4): 588-596.

Al-Suhaibani, S.A., A.A. AL-Janobi and Y.N. Almajhadi (2006).Tractors and tillage implements performance. CSBE/SCGAB 2006 Annual Conference Edmonton Alberta July 16 - 19, 2006, Paper No. 06-129

ASAE (2000). ASAE Standards D497.4 Agricultural Machinery Management Data, In: ASAE Standards 2000, (372-380) St. Joseph, MI. 
Askari, M. and S. Khalifahamzehghasem (2013). Draft force inputs for primary and secondary tillage implements in a clay loam soil. World Applied Sciences Journal, 21 (12):1789-1794.

Bolton, W. (1994). Engineering science, 2nd ed. Oxford: Newnes.

David, A. M., M. Banzi, D. Cuartielles and T. Lgoe (2007). Arduino: an open electronics prototyping platform. Conference on human factors in computing systems San Jose, California, USA.

Dedrick, R.R., J.D. Halfman and D.B. McKinney (2000). An inexpensive, microprocessor-based, data logging system. Comput. Geosci., 26:1059-1066.

Elashry, E. R., A.M. Bassuni, A. A. Sayed Ahmed and K.A. Ahmed (1994). An instrumentation system for measuring the tractor performance. Misr J. Agric.Eng.,11 (4):968-987.

El-Gwadi, A. A. (2005). Developing a locally manufactured slip ring torque transducer for PTO operating implements. Annual Conference of the Misr Society of Agr. Eng., 14-15 December 2005.

Ferdoush, S. and X. Li (2014). Wireless sensor network system design using raspberry $\mathrm{Pi}$ and Arduino for environmental monitoring applications. The 9th International Conference on Future Networks and Communications (FNC'2014)/The 11th International Conference on Mobile Systems and Pervasive Computing (MobiSPC'14), Ontario, Canada, August 17-20, vol. 34, pp. 103110.

Fisher D.K. and H. Kebede (2010). A low-cost microcontroller-based system to monitor crop temperature and water status. Comput. Electr. Agric. 74:168-73.

Fisher D.K. and P.J. Gould (2012). Open-source hardware is a low-cost alternative for scientific instrumentation and research. Modern Instrument. 1:8-20.

Ghaly, A. and S. Al-Suhaibani, (2010). Effect of plowing depth of tillage and forward speed on the performance of a medium size 
chisel plow operating in a sandy soil. American Journal of Agricultural and Biological Sciences, 5:247-255.

Harrigan, T. M. and C.A. Rotz (1994). Draft of major tillage and seeding equipment. ASAE Paper No. 94-1533. ASAE, St. Joseph, MI 49085.

Hoffmann, K. (2001). Smart Materials. Berlin, Heidelberg: Springer Berlin Heidelberg.

Hut, R. (2013). New observational tools and data sources for hydrology: hydrological data unlocked by tinkering. Master Thesis, Delft University of Technology, Amsterdam, Netherlands.

Iman, A. (2017). Evaluation of a chisel plow draft force and power estimation as based on the required mechanical laws. Iranian Journal of Biosystems Engineering (Iranian Journal of Agricultural Sciences), 47 (4): 625- 632 (Abstract in English).

Jithender, B., D.V. Sunitha, K. Upender and K.V.S. R. Reddy (2017). Performance study of tractor operated rotary plough in two different soils. Int. J. Curr. Microbiol. App.Sci., 6(10): 871-878.

Kadimi, J. and R. J. Dheeraj (2014). The TRACALTOR: automated farm area calculator and direction monitoring. International Journal of Computer Applications, 106(5):29 -32.

Kashyap, N. (2015). Design of low cost multi channel data acquisition system for meteorological application. Unpublished MSc Thesis, Department of Electronics and Communication Engineering National Institute of Technology, Rourkela, Odisha.

Khadr, Kh.A.A. (2004). Energy requirements for some seed-bed preparation implement under Egyptian conditions. The 12th annual conference of the Misr Society of Agricultural Engineering, PP: 481-491.

Khadr, Kh.A.A. (2008). Effect of some primary tillage implement on soil pulverization and specific energy. Misr J. Ag. Eng., 25(3): 731745 . 
Mayer, F. T. (2016). Development of a measuring system to detect oads acting between the binding and the roller ski. Master Thesis in Mechanical Engineering, Norwegian University of Science and Technology, Faculty of Engineering Science and Technology, Department Engineering Design and Materials.

Nada, A.A. (2003). Developing an electric continuous mass fuel measuring system. The $11^{\text {th }}$ Annual conference of Miser society of Agr. Eng. Oct. 2003: 273-282.

Nassir, A.J., M. N. Ramadhan and S.D. Mohssein (2016). Studying draft requirements and plowing specifications for chisel plow in silty clay soil. AL-Muthanna Journal of Agricultural Sciences, 4(1):100-119 (In Arabic).

Ndisya, J., A. Gitau, D. Mbuge and A. Hiuhu (2016). The effect of the operational parameters on the draft requirement of ripping in a sandy clay soil. Open Journal of Optimization, 5: 1-13.

Ranjbarian, S., M. Askari and J. Jannatkhah (2017). Performance of tractor and tillage implements in clay soil. Journal of the Saudi Society of Agricultural Sciences, 16(2):154-162.

Rasool, S., H. Raheman and G. Upadhyay (2017). Development of an instrumentation system for evaluating the tractive performance of walking tractors. International Journal of Current Microbiology and Applied Sciences, 6(10):759-770.

RNAM, (1995). RNAM test codes and procedures for farm machinery/Economic and Social Commission for Asia and the Pacific, Regional Network for Agricultural Machinery. RNAM technical publications: 12. Bangkok, Thailand.

Sahu, R.K. and H.A. Raheman (2006). Draught prediction of agricultural implements using reference tillage tools in sandy clay loam soil. Biosystems Engineering, 94:275-284.

Singh, C. D. and R. C. Singh (2011). Computerized instrumentation system for monitoring the tractor performance in the field. Journal of Terramechanics, 48(5): 333-338. 
Ştefănescu, D. (2011). Handbook of Force Transducers: Principles and components. Berlin: Springer Verlag.

Tatović, M., A. Milovanović and I. Karapandžić (2016). Device for the remote measurement of meteorological data based on Arduino platform. Serbian Journal of Electrical Engineering,13(1):133-144.

Teli, S. and C. Mani (2015). Smart real time embedded Arduino based data acquisition system. International Journal of Research in Engineering and Technology, 4(8):258-262.

Thalheimer, M. (2013). A low-cost electronic tensiometer system for continuous monitoring of soil water potential. Journal of Agricultural Engineering, 44(3), p. e16.

Younis, S. M., E. R. Elashry, A. F. Bahnasy and I. M. Elsybaee (2010). Development a local system for measuring tractors performance. Misr J. Ag. Eng., 27(1):34 - 53.

Zadeh, S.R. A. and R. L. Kushwaha (2006). Development of a tillage energy model using a simple tool. CSBE/SCGAB Annual Conference, Edmonton Alberta, July 16 - 19, 2006: 1- 14.

الملخص العربي

تطوير وحدة قياس وتسجيل بيانات القدرة تعتمد على لوحة الأردوينو

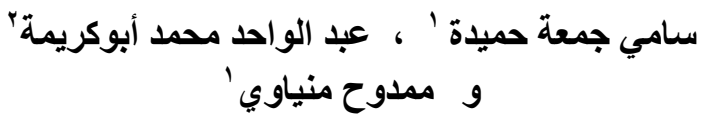

هدف البحث إلى التحقق من استخدام لوحة الأردوينو في تطوير وحدة قياس وتسجيل بيانات القدرة للمعدات الزراعية، حيث نم استخدام جهاز قياس الثند و المعتمد على مبدأ عمل وحدات

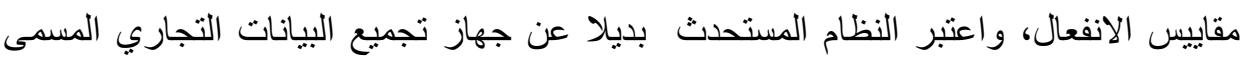
Khadr و المستخدم مع نفس جهاز قياس الثد في تجارب Daytronic system 10K4 (2008). وتعتبر لوحة الأردوينو رخيصة الثمن وسهلة البرمجة. تم اجر اء المعايرة المعملية

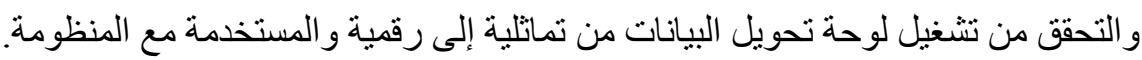

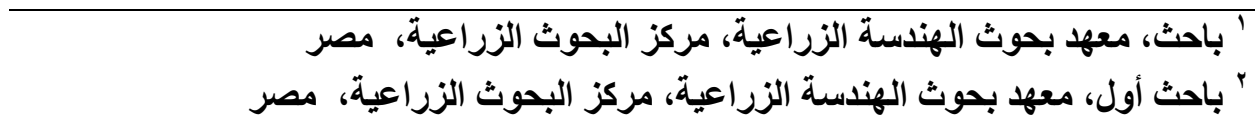


تم توصيل جهاز قياس الثد مع لوحة تحويل البيانات مع اللوحة الاليكترونية (الأردوينو) ليكونا

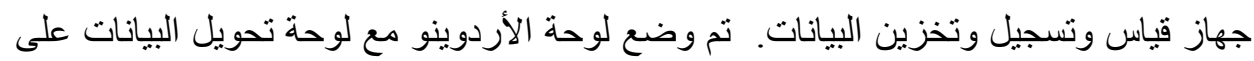

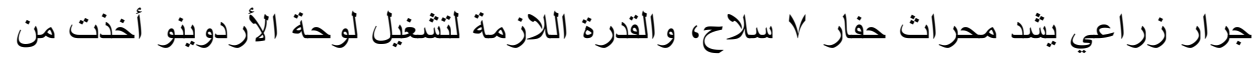

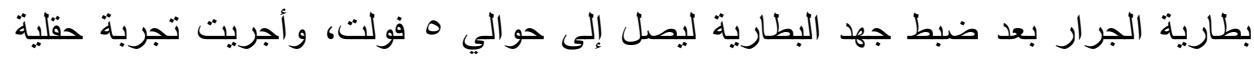

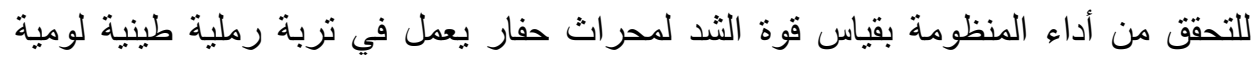
(sandy clay loam)

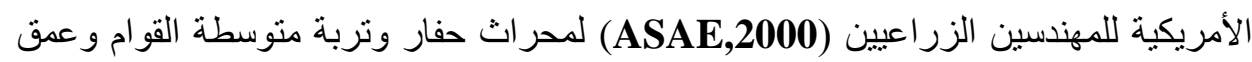

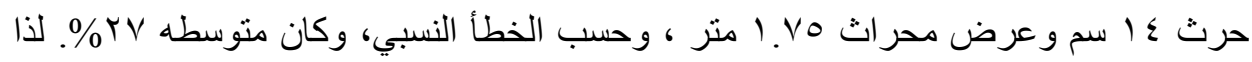

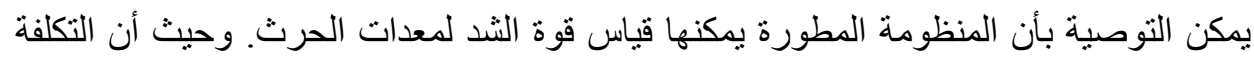

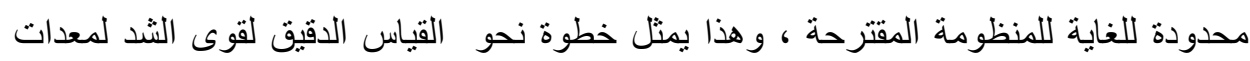

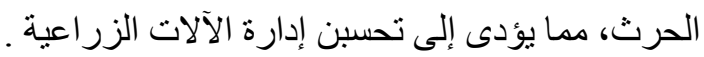

